Official Journal of the European Stroke Council

\title{
Cerebrovasculai Diseases
}

\section{Editors-in-Chief}

J. Bogousslavsky, Lausanne M.G. Hennerici, Mannheim

\section{Associate Editor}

J.D. Easton, Providence, R.I 


\section{Editorial Board}

J. Biller, Chicago, 111.

M.G. Bousser, Paris

L.R. Caplan, Boston, Mass.

M. Fisher, Worcester, Mass.

J. van Gijn, Utrecht

P.J. Koudstaal, Rotterdam

W. Kuschinsky, Heidelberg

\section{Advisory Board}

H. Adams, Iowa City, Iowa

F. Aichner, Innsbruck

S. Al Deeb, Riyadh

K. Asplund, Umea

J.-C. Baron, Caen

G. Boysen, Hvidovre

J.C.M. Brust, New York, N.Y.

L. Candelise, Milan

R. Cote, Montreal

P. Dalai, Bombay

GJ. Del Zoppo, La Jolla, Calif.

J.L. De Reuck, Gent

G.A. Donnan, Melbourne

J.M. Ferro, Lisbon

J.C. Gautier, Paris

D.L Graham, Glasgow

W. Hacke, Heidelberg

A. Hakim, Ottawa

W.-D. Heisi, Cologne 
J.-L. Mas, Paris

J.W. Norris, Toronto

B. Norrving, Lund

T. Sawada, Osaka

C.P. Warlow, Edinburgh

S.G. Waxman, New Haven, Conn.

H. Zeumer, Hamburg

M. Hommel, Grenoble

D. Inzitari, Florence

G.L. Lenzi, Rome

S.R. Levine, Detroit, Mich.

D. Leys, Lille

J.L. Marti-Vilalta, Barcelona

J. Matias-Guiu, Alicante

H. Mattle, Berne

J.P. Mohr, New York, N.Y.

M.A. Moskowitz,

Charlestown, Mass. J.-M. Orgogozo, Bordeaux

F. Regli, Lausanne

D. Russell, Oslo

H. Schafer, Marburg

G. van Melle, Lausanne

N.G. Wahlgren, Stockholm

B. Weir, Chicago, 111.

\section{KAKGER}


Contents Vol, 5,1995

No.1

Editorial

AdHocReviewers(1994)

\section{Concerns in Stroke}

Acute Stroke Trials: From Morass to Nirvana? Bogousslavsky, J.

Anticoagulation in Very Elderly Patients

( $>80$ Years) with Stroke and Atrial Fibrillation

Koudstaal, P J.

\section{[Clinical Review}

Aortic Arch Atheroma and Stroke Donnan, G.A.; Jones, E.F.

\section{[Original Papers}

Hemispheric Lateralization of Cognitive Evoked Blood Flow 14 Velocity Changes Assessed by Simultaneous Bilateral Transcranial Doppler Sonography Thomas, C; Harer, C; Altenmiiller, E.; Dichgans, J.

Atenolol in Secondary Prevention after Stroke

21

Eriksson, S.; Olofsson, B.-O.; Wester, P.-O.

Primary Intracerebral Haemorrhage in the Oxfordshire 26 Community Stroke Project. 2. Prognosis

Counsel!, C; Boonyakamkul, S.; Dennis, M.; Sandercock, P.; Bamford, J.; Bum, J.; Warlow, C. 
Antithrombin IU and Low-Dose Heparin in Acute Cardio-

embolic Stroke

Yasaka, M.; YamaguchvX; Moriyasu, H.; Oita, J.; Sawada, T.;

Omae, $\mathrm{T}$.

Follow-Up of Patients with History of Cervical Artery

Dissection

Leys, D.; Moulin, Th.; Stojkovic, T.; Begey, S.; Chavot, D.

Increased Levels of Leukocyte Elastase in Ischemic Stroke and

in Subjects with Vascular Risk Factors

Grau, AJ.; Seitz, R.; Immel, A; Steichen-Wiehn, C; Hacke, W.

Delayed Unilateral Akathisia with Posterior Thalamic Infarct

55 Ghika, J.; Bogousslavsky, J.; Regli, F.

\section{Case Report}

The 'Alien Hand' after Mesencephalic Haemorrhage

Diehl, RJL; Kietzsch, C; Berlit, P.

\section{Letter to the Editor}

Midbrain Ataxia Related to Cms cerebri Infarct

Nighoghossian, N.; Trouillas, P.; Riche, G.; Getenet, J.C.;

Neuschwander, $\mathrm{Ph}$

Newsletter of the European Stroke Council 
No. 2

\section{Cerebral Embolism}

Editor: Michael Hennerici, Mannheim

\begin{tabular}{lc}
\hline Editorial & 69 \\
Hennerici, M. & \\
\hline Embolic versus Nonembolic Causes of Ischemic Stroke & 70 \\
Martin, R.; Bogousslavsky, J. &
\end{tabular}

Clinical Presentation and Frequency of Potential Sources of

Embolism in Acute Ischemic Stroke Patients: The Experience

of the Rome Acute Stroke Registry

Fieschi, C; Sette, G.; Fiorelli, M.; Argentine, C; Toni, D.;

De Michele, M.; Bragoni, M.; Aguglia, F.; Bertazzoni, G.; Bozzao, L.

Clinical Diagnosis of Brain Embolism Caplan, L.R.

Coagulation and Fibrinolysis. From Plasma to Vessel Wall

Kienast, J.

The Coagulation Explosion Mann, K.G.; Kalafatis, M.

Brain Endothelial Cells, Atherosclerosis and Thromboembolism Yatsu, F.M.; Alam, R.; Alam, S.S.; Bui, G.

Arterial Thrombosis as a Consequence of 'Quasi-Chaotic* Coordination of Mechanical and Chemical Events Schmid-Schonbein. H.

A Brief View of Strange Attxactors Saupe, D.

Experimental Embolic Events

Markus, H.S. 
Silent Emboli and Their Relation to Clinical Symptoms in 121

Extracranial Carotid Artery Disease Sitzer, M.; Siebler, M.; Steinmetz, H.

High Intensity Transient Signals and Carotid Artery Disease 124 Ries, S.; Schminke, U.; Daffertshofer, M.;

Schindlmayr, C; Hennerici, M.

Relationship of Common Carotid Artery High Intensity Tran- 128 sient Signals in Patients with Ischemic Stroke to White Matter versus Territorial Infarct Pattern on Brain CT Scan Tegeler, C.H.; Knappert, V.A.; Nagaraja, D.;

Mooney, M.; Dalley, G.M.

Patent Foramen Ovale: A Potential Source of Cerebral 133

Embolism?

Schminke, U.; Ries, S.; Daffertshofer, M.; Staedt, U.; Hennerici, M.

New Trends and Developments in Magnetic Resonance 139

Imaging

Schwart, A.

Ultrasonic Quantitative Flow Volumetry of the Carotid 145

Arteries: Initial Experience with a Color Flow M-Mode System Eicke, B.M.; Tegeler, CH.

Experimental Cerebral Embolism. Hypotheses on the Mecha- 150 nisms of Hemorrhagic Transformation and Neuronal Loss without Infarction Molinari, G.F.

Design Considerations for the Warfarin-Antiplatelet Recurrent 156

Stroke Study

Mohr, J.P. and the WARSS Group

Author Index Vol. 5, No.

2,1995 Subject Index Vol.

Author Index Vol. 5, No. 2, 1995

158

Subject Index Vol. 5, No. 2,1995

158 
Contents 
No. 3 
No. 4

Concerns in Stroke 


\section{Abstracts}

Extrapolation of Trials Data into Practice: Where Is the Limit? 159 yan Gijn, J. 
Worst-Case Scenario: Management in Poor-Grade Aneurysmal 163

Subarachnoid Hemorrhage

Wijdicks,E.F.M.

[Original Papers 


\section{Reviews}

Functional Recovery after Brain Infarction. A Review of Experimental Animal Data Johansson, B.B. 
Hennerici, M.; Bogousslavsky, J.

Effect of Cholesterol-Lowering Medications on Progression of 171 Mild Atherosclerotic Lesions of the Carotid Arteries and on the Risk of Stroke Adams, H.P.; Byington, R.P.; Hoen, H.; Dempsey, R.; Furberg, $C D$.

Transcranial Doppler May Reveal Asymptomatic Cerebral

178

Vasculopathy in Systemic Lupus erythematosus

Cs`pany, T.; Valikovics, A.; Fulesdi, B.; Kiss, E.; Szegedi, G.; Csiba, L.

Survival with Basilar Artery Occlusion

Brandt, T.; Pessin, M.S.; Kwan, E.S.; Caplan, L.R.

Role of Vascular Risk Factors in Lacunar and Unexplained

Strokes in Young Adults: A Case-Control Study Ferro, J.M.; Crespo, M.; Ferro, H.

Validation of Transcranial Doppler Sonography in the Assess- 194

ment of Patent Foramen Ovale

Anzola, G.P.; Renaldini, E.; Magoni, M.; Costa, A.; Cobelli, M.;

Guindani,M.

Usefulness of Three-Dimensional Time-of-Flight MR AngioTabuchi, M.; Ohsumi, Y.; Yoneda, Y.; Mori, E.

A History of Monoparesis Does Not Differentiate between

199 graphy for Evaluation of Carotid Artery Bifurcation Stenosis Uebara, T.; Superficial and Small Deep (Lacunar) Infarction Boiten, J.; Kappelle, LJ.

\section{Case Report}




\section{Short Reports}

Early Local Intra-Arterial Thrombolysis for Severe Middle

Cerebral Artery Stroke

Bollaert, P.-E.; Bracard, S.; Boulanger, T.; Picard, L.; Larcan, A,

So-Called Capsular Genu Syndrome due to Noncapsular

Strokes

Kim,J.S.

Slow-Flow Dural Carotid-Cavernous Sinus Fistula.

Conservative Treatment and Non-Invasive Monitoring Busby, M.I.; Bamford, J.M.

Cardiac Catheterization Complicated by Stroke: 14 Patients

304 Ayas, N.; Wijdicks, E.F.M.

Aspirin Dosage - A Never-Ending Story? Hennerici, M.G.

Letters to the Editor

Familial Occurrence of Dissection of the Cervical Arteries

Neau, J.-Ph.; Masson, C; Vandennarcq, P.; Dumas, P.; Levillain, P.; Tantot, A-M.; Masson, M.; Gil, R.

Perimesencephalic Haemorrhage in the Quadrigeminal

Cistern

Rinkel, G.J.E.; van Gijn, J.

Transcranial Doppler Detection of Microemboli in a Stroke

Patient with Polycythemia rubra vera

Del Sette, M.; Finocchi, G; Angeli, S.; Conti, M.; Gandolfo, C. 
Positional Cerebral Ischemia Ginraeu, A.; Rey, A; Martf-Vilalta, J.L.

Announcements 
273.314

Issues in Stroke

The Diagnostic Evaluation of Transient Global Amnesia

Section Editor: Easton, J.D. 
No. 5 


\section{Review}

New Echocardiography Markers of Embolic Risk in Atrial Fibrillation

Di Pasquale, G.; Urbinati, S.; Pinelli, G.

FfffR.........!E...

Transesophageal Echocardiography in the Evaluation of Young 323

Adults with Ischemic Stroke: Promises and Concerns

^. d..!f.^>«'. ." i^^?lf."f.*

Original Papers

Epileptic Seizures after Thromboembolic Cerebral InfarctsS1 328 A Positron Emission Tomographic Study

De Reuck, J.; Decoo, D.; Algoed, L.; Boon, P.; Van Made, G.; Lemahieu, I.; Strijckmans, K.; Goethals, P.

A Randomized, ASA-Controlled Trial of Mesoglycan in Secondary Prevention after Cerebral Ischemic Events

Forconi, S.; Battistini, N.; Guerrini, M.; Passeio, S.G.

Effect of Tirilazad Mesylate on Middle Cerebral Artery 342

Occlusior ${ }^{\wedge}$ Reperfusion in Nonhuman Primates

Mori, E.; Ember, J.; Copeland, B.R.; Thomas, W.S.; Koziol, J.A.;

delZoppo,G.J.

Management of Subarachnoid Haemorrhage: A Decision Anal- 350 ysJs J

Dippel,D.WJ.; van CreveLR; Lindsay, K.W.:Hijdra, A-

uAl 1 T i-» 1 ?

Habbema, J.D.F.

Management of Transient Ischemic Attacks by the General

Practitioner

Otten, A.; Nino, Y.B.; Limburg, M.; de Haan, R.

Early Presentation of AcuteStroke in a Chinese Population 362

Ming, U Fisher, M.; Guanggu, Y.; Hongbo, Z.

Registration of RiskFactors for Stroke in Hospital Records 366

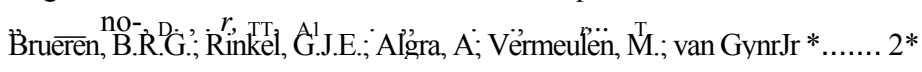

Issues in Stroke

The Temporal Arteritis Dilemmas

Easton, J.D.

Erratum

Announcements

341,374
Issues in Stroke

Does Alcohol Prevent or Cause Stroke?

Easton, J.D.

\section{Original Papers}

Stroke-Associated Pathological Sympathetic Activation 381

Related to Size of Infarction and Extent of Insular Damage

Sander, D.; Klingelhofer, J.

Relevance of Aging in Carotid Disease: Results of a Population 386 Survev

Parnetti, L.; Santucci, A.; Menculini, G.; Cherubini, A.; Senin, U.

Infrequency of Stroke Caused by Speofic CoagulaHon
-1

Haberl $>$ RL- Biniasch, (X; Ott, M.; Peinemann, A; Wick, M.; Kempter, B.

334

${ }^{\mathrm{Do}} \mathrm{PP}^{\text {ler } C} 0_{* * * *}$ Diamox Test: $\wedge$ creased Reliability by Chan ${ }_{\mathrm{eS}} \mathrm{S}$ of $\wedge$ VeSSel Diameter?

KJeiser, B.; Scholl, D.; Widder, B.

Subarachnoid Haemorrhage after Head Injury

Kakarieka, A.; Braakman, R.; Schakel, E.H.

Prognostic Value of MEP and SSEP in Patients with Chronic 407

UMN Lesions after Stroke

Stephan, K.M.; Netz, J.; Homberg, V*.

«j-.-.......-...-........

Letters to the Editor

Stroke Trials

Dehaene, I.

Combined Expertise in Stroke Trials

Norris, J.W.; Djan, P. Jii^ReJiort

Quantmcation of Atheromatous Stenosis in the Extracranial

Internal Carotid Artery

de Bray, J.M.; Glatt, B.

Author Index Vol. 5,1995

Subject Index Vol. 5,1995

Suppl. 1

Trials for Acute Stroke Therapy

Janssen-Cilag Symposium at the Fourth European Stroke Conference, Bordeaux, June 1,1995

Editors: J. Bogousslavsky, Lausanne, Switzerland; P. Koudstaal, Rotterdam, The Netherlands; H.J.M. Barnett, London, Canada 
